\title{
Cross-border E-commerce Trade between China and Africa: Review of the Literature
}

\author{
Jiling Li ${ }^{1} \&$ Jürgen Bode ${ }^{2}$ \\ ${ }^{1}$ Northwest University of Political Science and Law, Xi'an, P.R. China \\ E-mail: jiling.li@h-brs.de; 345196182@qq.com \\ ${ }^{2}$ Hochschule Bonn-Rhein-Sieg University of Applied Sciences, Sankt Augustin, Germany \\ Email: juergen.bode@h-brs.de \\ https://doi.org/10.47963/jobed.2020.04
}

\begin{abstract}
This article explores the opportunities, challenges, as well as the activities of the Chinese governmental and commercial stakeholders to promote cross-border e-commerce trade between China and Africa, based on the classification and correlation analysis of the literature from 2011 to 2019 . The results show that the biggest driver for the development of China-Africa cross-border e-commerce trade is the gap between the rapid growth of the African population, especially the middle class, and the limited local capability to satisfy their demand. The rapid development of the internet and mobile internet is another driving factor. The biggest challenge is the last mile delivery of logistics, and online payment issues in Africa. At the macro-level the Chinese government has promoted measures such as infrastructure investment, e-commerce test zones and the establishment of pilot projects. At the firm level, Chinese companies have focused on solving practical micro-level local operational problems such as logistics, online payment, and talent training. The results also show that the referred literature is still in its infancy, mostly theoretical and less practical, and requires more in-depth domain specific analysis in the future.
\end{abstract}

Keywords: Africa, China, cross-border trade, e-commerce, literature review, trade 


\section{Introduction}

With the overall slowdown of global trade growth in past years, the development of China's import and export trade has also decelerated. In contrast, China's cross-border e-commerce has experienced rapid development. From the scale of transaction perspective, it has shown continuous rapid growth, and accounted for $27.5 \%$ of the total foreign trade in 2016 (Guo, Ming, Wang, \& Zhu, 2018). From the transaction volume perspective, it has exceeded nine trillion RMB from 2014 to the end of 2018, which had doubled in five years ( $\mathrm{Li}, 2020)$. Therefore, the cross-border e-commerce is becoming an indispensable and important part of China's foreign trade. Cross-border e-commerce refers to international trade in which companies or individuals belonging to different customs areas use the Internet to match supply and demand and conclude a trade contract, with the settlement of funds and the delivery of goods and services following thereafter. Cross-border e-commerce results in the import and export of goods and services. Depending on the type of stakeholders involved on both sides of the trade, it is commonly distinguished between Business to Business trade (B2B), Business to Consumer trade (B2C), and Consumer to Consumer trade (C2C) (.Guo et al., 2018).

In the global e-commerce landscape, Africa is generally considered to have a great potential for further development. According to Frost \& Sullivan's estimates dating from 2018, the size of the African e-commerce market will have reached US $\$ 50$ billion in 2018, attracting a large number of investors and entrepreneurs into this market (.Liu \& Li, 2018). Under such circumstances, China-Africa cross-border e-commerce is expected to thrive. However, as outlined below there are also multiple obstacles and challenges to be mastered (.Xu \& Qing, 2018).

The purpose of this article is to investigate the opportunities and challenges in the cross-border e-commerce trade between China and Africa, and the related activities of the Chinese government and firms. The analysis will provide a starting point for subsequent theoretical research and practical activities. Enterprises and governments worldwide can benefit from learning about the Chinese experience in order to promote their cross-border e-commerce with Africa.

\section{Methodology}

This article is based on a comprehensive theoretical literature review of sources in Chinese and English language. The search period was set from 2011 to 2019. This is the period when African e-commerce began to emerge and gradually develop, and where journals, articles and reports could be obtained easily, and with sufficient scope.

Four steps of research were followed. First, identification of research keywords. The research was started with search terms such as "China-Africa e-commerce", "China-Africa cross-border e-commerce", "Africa e-commerce", "Africa cross-border e-commerce". The search results were evaluated, and references from these sources were used for further investigation ("snowball method").

Second, identification of sources of both Chinese and English languages. Literature retrieval in Chinese: Search articles published on China National Knowledge Infrastructure (CNKI) from 2011 to 2019, as well as articles published on authoritative sources, such as People's Daily Online, Xinhua Daily, Ministry of Foreign Affairs website, Alibaba Research Institute, Economic Daily, etc. Literature retrieval in English: Search articles retrieved through Springer Link and Google Scholar from 2011 to 2019, as well as articles published on authoritative sources, such as the Ecommerce Foundation, United Nations Industrial Development Organization (UNIDO), United Nations Conference on Trade and Development (UNCTAD), Global System for Mobile Communications Alliance (GSMA), etc.

Third, search results filtering. By establishing the correlation between the content of the search results and the theme of this paper, the usefulness of the retrieved literature was determined. Thirty-two sources in Chinese language and 23 sources in English language were finally selected. Fourth, content classification and correlation analysis of selected sources. The main content of the above 55 documents was analyzed; opportunities, challenges and measures described in each source were extracted and summarized, and the results presented in the form of a table (see Appendix I).

\section{Literature Review and Discussion}

Opportunities and drivers for cross-border e-commerce trade between China and Africa

As summarized in Figure 1, the rapid development of the China-Africa cross-border e-commerce market is driven by multiple factors, including the rapid development of the Internet and mobile communication, a low level of development of the local e-commerce industry, a large number of emerging new consumers, and support of policies and regulations. These factors indicate a substantial market potential. 


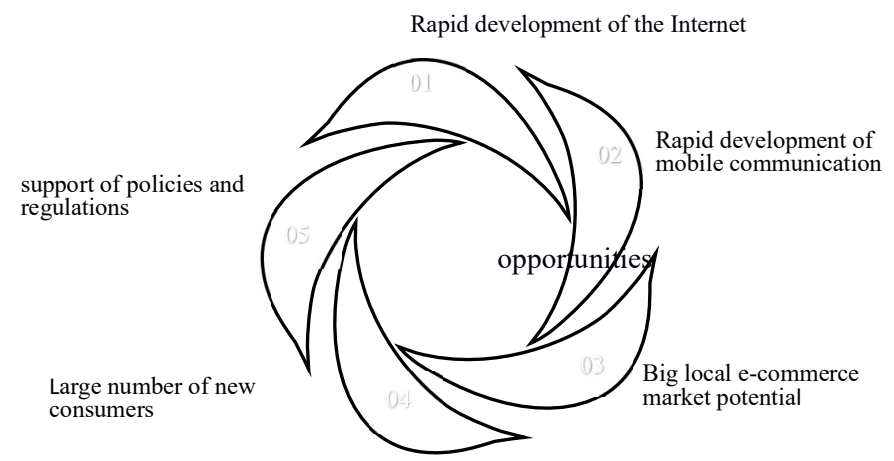

Figure 1: Drivers and opportunities for China-Africa cross-border e-commerce trade

First, rapid development of the Internet. Abundant literature is available in this area. Most researchers mainly analyzed from the perspective of investment in Internet infrastructure construction and network coverage in African countries. They believe that the current popularity and utilization of Internet in African countries have greatly increased, which provides good conditions for the development of e-commerce (Huang, 2019; .Liu \& li, 2018; .Xu \& Qing, 2018; Zhu \& Song, 2018). The Internet penetration rate has continued to increase from $25 \%$ in 2015 to $43 \%$ (forecast) in 2018, as shown in Figure 2 (Lone, Fávero \& Packiarajah, 2018).

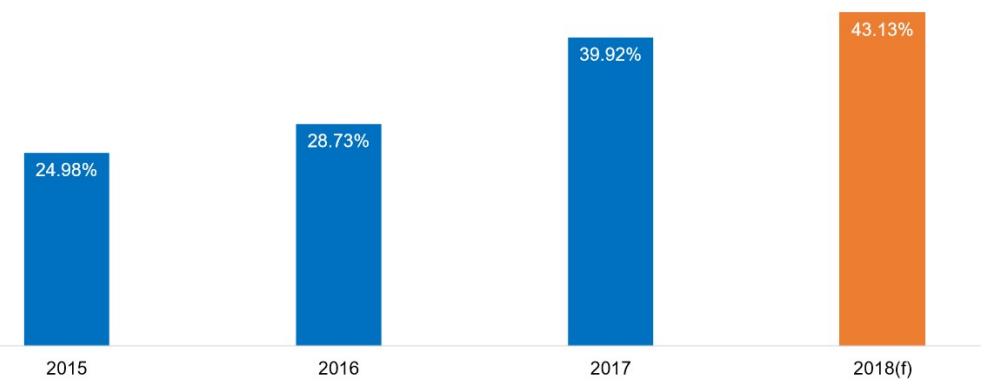

Figure 2 Internet penetration in Africa

Source: Ecommerce Foundation; Worldometers, $2018 *$ Countries incl: Nigeria, South Africa, Egypt, Algeria, Morocco, Kenya, Angola, Ghana, Ethiopia, Sudan, Tanzania, Tunisia

In Nigeria, the Internet penetration rate reached $70 \%$ in 2018 , and it also has the most e-commerce sites among Africa's countries. $40 \%$ of African e-commerce companies are headquartered in Nigeria. In Kenya, the Internet penetration rate in 2018 was $79 \%$, and Kenya is the headquarters of M-Pesa, a mobile wallet provider launched by Vodafone in 2007. 85\% of Kenyans use electronic payment methods, including bank accounts, mobile prepaid cards or other payment products (Lone et al, 2018). South Africa has the most advanced telecommunications network infrastructure among the emerging markets (Killian \& Kabanda, 2017), with an Internet penetration rate of $65 \%$. South Africans have begun shopping on US, UK, and Chinese websites (Lone et al, 2018).

Second, rapid development of mobile communication. From the analysis of the literature, Africa's e-commerce market is mainly mobile, and mobile e-commerce is the cornerstone of African e-commerce development. The combination of mobile networks and mobile payment has opened up good shopping opportunities for areas with very few physical stores and goods, as well as a favorable environment for cross-border e-commerce. Africa has the fastest growing smartphone market globally (Huang, 2019). According to the research firm Statista, mobile device usage in Africa reached $61 \%$ in 2018 , which is much higher than the usage of any other device, as shown in Figure 3 (Lone et al, 2018). Global Mobile Communications Alliance (GSMA) data showed that by the end of 2015, 46\% of Africans have registered for mobile services (.Xu \& Qing, 2018), and the number of mobile users in sub-Saharan Africa is expected to increase from 456 million at the end of 2018 to more than 600 million by 2025, accounting for about half of the region's population (China-Africa Trade Research Center, 2019). Ovum, a telecommunications consulting company, predicts that the number of mobile subscribers in Africa will reach 1.32 billion in 2020 (Xu \& Qing, 2018). 


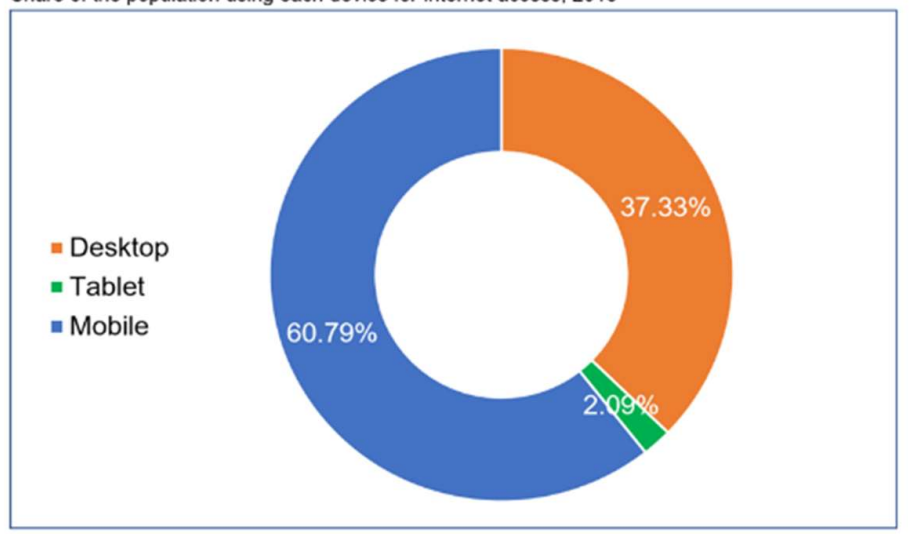

Figure 3 Majority of population (61\%) uses mobile devices for internet access

Third, infancy of local e-commerce industry indicating large market potential. According to the literature that the overall African industry is in a low development stage, the productivity is low, and the product availability hardly meets market demand. The early stage of Africa's industrialization is manifested in the low manufacturing output value, the low employment rate of manufacturing workers and the low export volume of high-tech manufactured products (.Li, 2016). Between 1990 and 2011, the proportion of global manufacturing value added in sub-Saharan Africa increased by only $0.13 \%$, making it one of the regions with the smallest increase among the developing regions (United Nations Industrial Development Organization [UNIDO], 2015). African countries, especially those in subSaharan Africa, have an unbalanced industrial development and a relatively poor industrial base, resulting in a scarcity of local goods, lagging retail development, and a small number of physical stores. Thus, consumers have a significant demand for overseas products (.Liu \& Wang, 2019). The emergence of cross-border e-commerce has changed the pattern of the traditional trade value chain. In contrast to traditional Chinese foreign trade commodities, such as textiles and clothing, electronic products are less difficult to transit to e-commerce, and their products are highly competitive in the African market (.Xu \& Qing, 2018). Chinese commodities have enriched the consumption choices of African people, and diversified products have met the needs of consumers at different levels (.Xu \& Qing, 2018).

Fourth, large number of new consumers. Most authors believe that the rapid population growth in Africa, especially the rapid growth of the middle class, is an important driving factor for the development of e-commerce. The African demographic dividend will result in a large demand in the African e-commerce market (Zhu \& Song, 2018). The population of Africa is growing rapidly, forecast to reach 2.5 billion by 2050 and exceed 4 billion by 2100 (Pison, 2017). The number of households belonging to the middle class has increased by $230 \%$ since 2000 among the 11 countries with the best economic performance in sub-Saharan Africa (Economic and Commercial Office of the Embassy in the Republic of Congo, 2014). As disposable income increases, this rapidly growing population, including professionals and business people, will surge in its demand for high-end goods abroad. Research firm Statista estimates that the revenue of African e-commerce industry is $\$ 16.5$ billion in 2017 and will reach $\$ 29$ billion by 2022 (Kaplan, 2018).

\section{Besides Support of Policies and Regulations}

In order to support and regulate the development of the e-commerce industry, many African countries have introduced relevant e-commerce laws and regulations: therefore, rich literature is available in this field. Tanzania's e-commerce legislation issued the "Electronic Transaction Act 2015" in 2015, followed immediately by the "National Information and Communications Technology Policy 2016"in 2016. These laws regulate e-commerce, other digital tools and the digital environment in general. In 2016, Kenya introduced the "Kenya Information and Communications (Electronic Transactions) Regulations 201," which provides the regulation of electronic transactions. In 2016, the South African National Information and Communications Technology Policy proposed to set up industry-specific strategies to encourage different industries to adopt and use ICTs and promote local ecommerce (Budree, 2017). In June 2019, the African Free Trade Area Agreement signed by 44 countries in Africa came into effect, and the world's largest single market was born. E-commerce will play an increasingly important role in the implementation of the African Trade Area and the digitalization of the African continent (Economic and Commercial Office of the Embassy in Guinea, 2019; Zhang \& Wang, 2019). These are just a few examples of policies 
promoting and protecting a beneficial environment for e-commerce, including cross-border e-commerce. They have the potential to provide a conducive environment for investment in that area.

\section{Challenges of Cross-border E-commerce Trade between China and Africa}

As summarized in Figure 4, the main challenges are high logistics cost and obstacles for online payments. Further challenges include limited trust in processes and stakeholders, market entry barriers, educational background of population and language barriers. The analysis shows where governments, companies and other stakeholders need to take measures in order to increase e-commerce between China and Africa. Many of the results also apply to ecommerce from other regions to Africa and are, therefore, helpful worldwide.

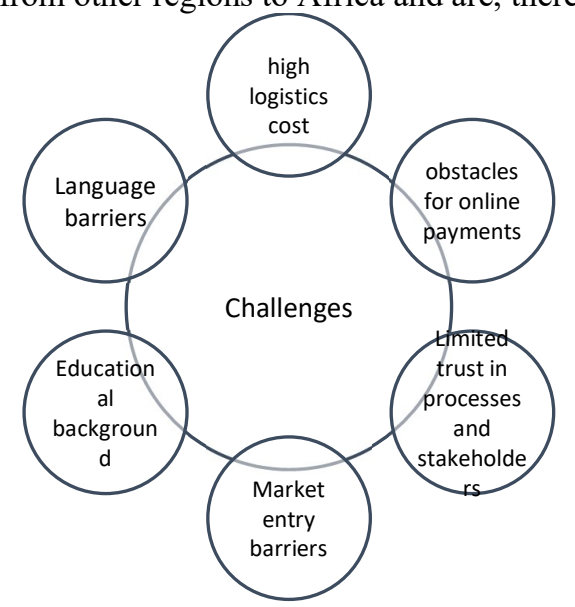

Figure 4 Main challenges for China-Africa cross-border e-commerce development

First, logistics costs are high due to infrastructure under development. From a logistics infrastructure perspective, the infrastructure is still poor in parts of Africa; the roads, ports and air transport are still under development, the power supply and postal services are not reliable (Huang, 2019; Pedroncelli, 2017; Wu \& Guo, 2019). The performance of infrastructure sectors and dimensions for most countries in Sub-Saharan Africa is dismal and that infrastructure is a bottleneck to development (Calderón, Cantú, \& Chuhan-Pole, 2018), preventing global logistics companies from entering many countries. From a logistics distribution perspective, most African countries lack a street address system (Matthews, 2016), which results in the lack of a domestic delivery service (.Li, 2018), and many of its residents live in rural areas (Ibam, Boyinbode, \& Afolabi, 2018). Therefore, the cost of the last mile delivery is expensive, the transportation time is long, and it is not easy to track the logistics process. These problems have become a significant obstacle for the development of Africa's e-commerce (Liu \& Wang, 2019).

Second, online payments are not yet widely accepted. Many authors consider the problems of online payment as another important obstacle to wider acceptance of e-commerce in Africa. Cash on delivery is the main payment method that online merchants, like Takealot, Jumia and Konga, must live with (Ibam et al., 2018). In Nigeria, the country with the best e-commerce development in Africa, $67 \%$ of users pay by cash on delivery, $23 \%$ pay by credit or debit card, of which $10 \%$ use mobile payment ("Mobile Report Nigeria 2018," n.d.).

The literature explains the low online payment rate along three factors. First, the penetration rate of payment cards in most African countries is low. There are only about 10 million credit or debit card holders in Egypt, accounting for about $10 \%$ of the total population. About $80 \%$ of e-commerce transactions are carried out by cash on delivery (Liu \& Wang, 2019; Lone et al., 2018). Second, most African countries do not have sufficient mobile commerce telecommunications infrastructure, and they lack appropriate legal frameworks and policies to regulate mobile payment systems (Gutierrez \& Choi, 2014); therefore, the security of cross-border banking and financial networks is not guaranteed. Third, because the domestic banking system lacks the necessary international connections, some countries in the region may only be able to collect payments from foreign credit card holders through expensive intermediaries. Although global e-commerce platform providers offer integrated payment solutions, many African companies cannot actually use these solutions, because they lack the necessary foreign bank accounts or subsidiaries (Pedroncelli, 2017). All of these affect the convenient payment and settlement of cross-border e-commerce, making cross-border trade inefficient.

Third, processes and stakeholders enjoy only limited trust. The issue of integrity is also one of the focal points of the literature, with network security and industry environment as the main causes of integrity issues. Africa has a comparatively high rate of online fraud: around 7\% of online transactions in Africa were fraudulent in 2012, especially in Nigeria and Ghana (Siwicki, 2013). A survey of South African users showed that most respondents replied that they prefer to touch the product before buying, $36 \%$ said they do not trust online payments, and $8 \%$ do 
not trust websites (United Nations Conference on Trade and Development [UNCTAD], 2015). In Egypt, the biggest obstacle to e-commerce adoption is said to be the issue of insufficient trust in security on the Internet (Zaied, 2012). Second, many African companies often do not have access to electronic trust tools such as digital signatures or certain security standards, so Chinese companies conducting cross-border trade on African e-commerce platforms face the challenge of winning the trust of consumers in these countries (Meltzer, 2014). In addition, the political instability in some African countries (Liu \& Li ,2018; Wu \& Guo, 2019; Xu \& Qing, 2018), immature e-commerce systems (Huang, 2019), insufficient credit mechanisms in the communications industry, and the inappropriate legal and regulatory system (Xu \& Qing, 2018) are also prominent reasons that hamper trust in processes and stakeholders.

Fourth, protectionist policies raise market entry barriers. The literature in the field of market entry mainly focuses on customs clearance policies and customs declaration procedures. Most African countries are currently pursuing protectionist policies with strict tariff and non-tariff barriers (Song, 2019), which apparently puts obstacles to international trade, including cross-border e-commerce. According to the South African customs procedures, the South African Taxation Agency (SATS) has about 90,000 product codes, which are strictly applicable to all imported products. Foreign exporters are strongly encouraged to seek local agents with a thorough understanding of South African law for customs clearance ("South Africa", 2019). Similarly, Nigerian customs clearance procedures are lengthy and complicated (Ibam et al., 2018), and cumbersome customs procedures may further hinder the smooth completion of cross-border e-commerce transactions (Lawrence, 2011; Liu \& Wang, 2019; Xu \& Qing, 2018). Due to the typical characteristics of e-commerce trade with its small and multiple batches, customs clearance through local agents will inevitably increase costs. Especially for small and medium-sized enterprises, there is a possibility that the customs clearance costs are too high and they will give up entering a country.

Fifth, the educational background is comparatively low. A study found that education level is positively correlated with the possibility of EU countries participating in cross-border e-commerce trade, and cross-border e-commerce transactions require a higher level of education (Valarezoa, Pérez-Amaralb, Garín-Muñozc, Herguera Garcíab \& Lópezb, 2018). The literature shows that the average education level of the population of most African countries is comparatively low at present (Liu \& Li, 2018; Xu \& Qing, 2018). This has two side effects; on the one hand, lower workforce qualification in Africa results in a lack of specialized digital talents who are able to develop, maintain and run an e-commerce infrastructure (Huang, 2019; Wu \& Guo, 2019). On the other side, Africa's literacy rate lags behind the world: only $64 \%$ of Africans can read and write. In the West, literacy rates are generally above $90 \%$, whereas in Asia it is even higher (Wanyonyi, 2018). The illiterate either do not use e-commerce platforms, which limits market size, or they require training, which increases the cost of e-commerce.

Besides, English as the main language in e-commerce creates barriers for large parts of the African population. The literature shows that Africa is the world's most linguistically diverse continent (Xu \& Qing, 2018). For example, Nigeria, Africa's largest populous country and the largest economy, has more than 400 languages in 250 tribes. There are 11 official languages in South Africa, and only 9.6\% are native English speakers. According to census data collected by the South African government in 2011, isiZulu is the most spoken language with 11.6 million speakers, followed by isiXhosa with 8.15 million and Afrikaans with 6.85 million. Seychelles is the smallest and least populous country in Africa with less than 100,000 people, but still there are three languages in use, i.e., English, French, and a French-based Creole (Wang, 2018). As 53.2\% of all websites use English as primary language, they are not accessible to many inhabitants of the continent, especially in countries where English is not a first or second language (Mzuku, 2016). In order to promote the development of e-commerce, it would be helpful to set up a platform in local language. $72 \%$ of consumers are more likely to purchase an item if the item is described in their native language, and local language has been found to be an even more important purchasing factor than price (E. Turban, King, Lee, Liang, \& Turban, 2015).

\section{Activities of the Governments and Firms}

Chinese and African governments and enterprises are exploring and practicing different measures in order to overcome the obstacles discussed in the previous section, and to promote the development of China-Africa crossborder e-commerce trade. The measures are summarized in Table 3 of Appendix I. The governments perform activities on macro level, such as transportation and communication infrastructure investment and construction, policy design and implementation, joint pilot projects. Firms are attempting to solve the obstacles at micro level, such as localization of operations and business websites, development of online payments, overseas warehouse construction, talent training, digital infrastructure construction, establishment of integration platforms. The measures on both levels have effectively supported the sustainable development of China-Africa cross-border e-commerce trade. 
Activities of governments

First, the Chinese government invests in transportation and communications infrastructure. According to the literature China and Africa have concluded co-operation plans on the digital economy, combining traditional infrastructure construction of railways, highways, power, bridges, and dams, with the construction of a digital networks infrastructure to realize a coordinated development of both types of infrastructure (Fang, 2019; Hung, 2019). The African Infrastructure Construction Consortium (ICA) released a report stating that from 2011 to 2016, China's investment in the African infrastructure sector averaged \$12 billion per year, which is Africa's largest source of investment in infrastructure (Economic and Commercial Office of the Embassy in Senegal, 2017). Promoted by cooperation agreements dating from 2017, China UnionPay Network has established networks in more than 50 countries in Africa to provide guarantee conditions for cross-border payments. In 2017, the export growth rate of cross-border e-commerce goods inspected and released by China Customs reached $41.3 \%$ (Ministry of Commerce of the People's Republic of China, Department of Electronic Commerce and Informatization, 2018). In July 2018, China committed to investing $\$ 14.7$ billion in South Africa and providing loans to its national power companies and logistics companies to support the expansion of South Africa's cross-border e-commerce infrastructure (Phoenix Business Daily, 2018).

Second, China has implemented cross-border e-commerce pilot projects, improved policies, regulations, and operating processes. In 2012, China began the construction and operation of "Cross-border E-commerce Pilot Cities", and in 2015 of "Cross-border E-commerce Comprehensive Experimental Zones" (CBEcCEZ). The design of CBEcCEZ encompasses relevant policy frameworks, including six systems (information sharing, financial services, intelligent logistics, e-commerce credit, statistical monitoring, and risk prevention and control systems) and two platforms (online comprehensive service platform and offline Integrated park), and realizes institutional innovation (Yang, 2017). In the first half of 2017, the combined sales of cross-border e-commerce import and export of 13 CBEcCEZs more than doubled over the previous year and exceeded 100 billion RMB. In 2013, the Chinese government started its "Belt and Road" Initiative, a set of large worldwide logistics projects, which has the potential to support the goals of the African "2063 Agenda" (Q. W. Zhang \& Zhang, 2016). The new Chinese E-Commerce Law, which came into effect in 2019, establishes and improves customs, taxation, entry-exit inspection and quarantine, payment and settlement management systems aimed to cater to the needs of cross-border e-commerce (Li, 2018).

\section{Activities of firms}

This section takes a case-based approach where we highlight activities of individual companies. The case examples have been clustered into six types of firm activities: localization of operations, development of online payments, construction of overseas warehouses and logistics, talent and skill development, construction of digital infrastructure, and the establishment of integration platforms.

First, firms have localized operations, management and language. Kilimall is an e-commerce platform established by a Chinese start up in Africa. It is currently the largest online shopping mall in Kenya. Kilimall has integrated local features into solution design, marketing and after sales services (Jessica, 2017) and established a local operation management team (Zhu \& Song, 2018). Alibaba Dharma Institute uses machine translation to help small and medium sellers on the Alibaba AliExpress platform to provide buyers and sellers with machine translation services in more than 20 languages to automatically translate product details and reviews into local languages. Real-time AI language translation of customer service and business consulting is also provided (Li, 2018), improving business and communication efficiency.

Second, companies have developed sophisticated online payment platforms. The most popular payment method for cross-border e-commerce shopping in Africa is cash on delivery, and mobile payment is the second after that. In East Africa, two thirds of adults use mobile payments often (Global Mobile Communications Alliance [GSMA], 2017). Consequently, Kilimall with its e-commerce platform in Kenya cooperates with the largest local mobile phone payment provider to collect payments from customers, and to transfer payments to sellers on the platform (Jessica, 2017). In 2015, Tencent cooperated with local banks in South Africa to launch its WeChat wallet service, which includes user-to-user money transfer, real-time ATM machine withdrawal, and offline code scanning payment services. Tencent's local partners include retailers such as SPAR, SPAR Tops and Cambridge Food Stores (Xu, 2015). In 2017, Alipay, a Chinese mobile payment solution, cooperated with Zapper, a South African payment company, to promote the development of online payment in Africa, further expanding the payment options of African users $(\mathrm{Li}$, 2017).

Third, firms have established overseas warehouses and logistics. To solve the last mile delivery problem and improve delivery efficiency, E-commerce company Kilimall is building its own logistics system in Kenya (Zhu \& Song, 2018). In a combination of self-operated logistics and third-party logistics, Kilimall sets up local self-operated intra-city logistics team for the last mile delivery, while inter-city delivery is undertaken by third-party logistics. Kilimall constructed overseas warehouses and stores products in demand in advance, so that customers can receive 
goods within 1-3 days after placing orders (Jessica, 2017). In 2015, Yuantong Express Co. Ltd. signed a co-operation agreement with the Zimbabwe Ministry of Posts and Telecommunications. Zimbabwe Post became the partner of Yuantong's parcel service from China to Zimbabwe and other countries and regions in southern Africa. Thus, the transfer time between China and Africa on the Rookie platform, an Alibaba joint venture with Yuantong and other logistic companies, has been shortened from an average of 70 days to 20 days. Diversified logistics solutions, such as Automated guided vehicle (AGV) robots, intelligent express boxes (cabinets), unmanned warehouses, and smart logistics parks are expected to improve Africa's logistics efficiency in the future (State Post Bureau of The People's Republic of China, 2018). The China National Building Materials Corporation has proposed a comprehensive foreign trade operation model of "cross-border digital trade and shared overseas warehouse" for Africa. It integrates ecommerce elements into the traditional international trade model and provides one-stop foreign trade for African countries, such as South Africa, Kenya, and Sudan (Secretariat of the Organizing Committee of the First ChinaAfrica Economic and Trade Fair, 2019).

Fourth, companies successfully developed talent and skills. In their quest to tap the market potential of ecommerce between China and Africa, Chinese companies are engaged in promoting e-commerce awareness and confidence among the African workforce and consumers. They offer IT training of local employees, improve the operational performance and high standard of online systems, aimed at increasing the knowledge of consumers about e-commerce, and attempt to raise confidence in electronic payment systems (Ibam et al., 2018). Huawei has trained more than 30,000 information and communications technology professionals in seven training centres in Africa. The "Seed of the Future" talent development project has been implemented in African countries such as Kenya, Zambia, and Zimbabwe. It is expected that 1,000 African students will benefit within five years (Xu, 2015). Alibaba has launched three training programs: Inviting African entrepreneurs to study in China, "African Internet Entrepreneur Fund," and "Jack Ma Africa Youth Entrepreneurship Fund." E-commerce education and skills training were held at the University of Rwanda in August 2018, attracting 50 university teachers from 9 universities, and aiming to cover 2,500 African students (Guo, 2018; Hou, 2018). In 2019, the Alibaba Group invited entrepreneurs from countries along the Belt and Road region to share knowledge about the digital economy. Of the more than 200 participants 87 were from Africa (AliResearch, 2019).

Fifth, Chinese companies contributed to the digital infrastructure construction. Chinese companies were involved in the construction of digital infrastructures in African countries. Huawei launched Africa's first ICT innovation experience centre in Johannesburg, South Africa, where visitors can experience research and development achievements such as 5G technology, virtual reality, and smart home (Xinhua News Agency, 2017). ZTE, a large Chinese network provider, has supplied products and services to virtually all countries in Africa (Zhang, 2015). As part of its corporate social responsibility (CSR) initiatives, Alibaba Group and the Kenyan Animal Protection Department jointly developed a "Wild Animal Intelligence Protection Project," which aimed to use big data and artificial intelligence technology to form a digital system for the protection of wild animals (AliResearch, 2019).

Besides, Chinese companies have strived to establish integration platforms. E-commerce platforms are moving towards intensification, integration of diverse value-added services, and integration with local platforms. All these trends simplify trade and increase usability. In 2017, the "China-Africa Cross-border E-commerce Platform with Comprehensive Supply Chain Integrated Services" was launched to facilitate the "information exchange, smooth trade, and cultural integration" of trade between China and Africa (Liu \& Li, 2018). Alibaba's Electronic World Trade Platform (eWTP) was launched in Rwanda. It provides an infrastructure for e-commerce in both directions, from China to Africa and vice-versa (Hou, 2018; Zhang \& Wang, 2019).

\section{Conclusion}

Based on the classification and correlation analysis of fifty-five documents from 2011 to 2019, this article explores the opportunities, challenges as well as the activities of governments and enterprises to promote cross-border ecommerce between China and Africa. The following conclusions can be drawn:

The potential business opportunities of cross-border e-commerce between China and Africa are large, and on a rapid growth path. The referred literature mostly provides an overall analysis on aspects like trade volume, population growth, Internet and mobile infrastructure development etc., often with a continent-wide horizon. However, the national or regional level analysis is to be strengthened to help understand the real development status of each country. This can help an e-commerce company to find the fine-grained customer requirements and targeted markets in Africa. Cross-border e-commerce between China and Africa still faces many challenges, the most significant ones being high logistics costs, low online payment rates, and complex customs procedures. The resolution of these issues is key for e-commerce development; however, the current literature mostly focuses on theoretical and general analyses of these challenges. Future research should tackle these domain specific issues more in-depth. It must be based on sound theory, but it would be helpful for practical policy and management if it also was clearly application oriented. This can be achieved by joint efforts of organizations (e.g., some e-commerce associations), enterprises and academics; therefore, joint research and publications are expected in the future. 
The Chinese government and firms are promoting the development of China-Africa cross-border e-commerce; African governments invest in infrastructure and have started to set up conducive regulations. Some joint pilot activities on governmental and firm level, such as cross-border e-commerce experimental zones, local warehouse and logistics infrastructure setup, online payment development, are good attempts to solve problems, firstly, on a small scale, and then promoting into broader scope. Further attention on how to standardize and promote these activities deserve deep study if they turn out to be valid measures for cross-border e-commerce development. Although this research focuses on e-commerce between China and Africa, we believe that enterprises and governments worldwide can benefit from learning about the Chinese experience in order to promote their crossborder e-commerce with Africa.

\section{Appendixes}

Table 1: Major drivers and opportunities for China-Africa cross-border e-commerce

\begin{tabular}{|c|c|c|}
\hline Theme & Drivers and Opportunities & Source \\
\hline $\begin{array}{l}\text { The development of } \\
\text { the Internet }\end{array}$ & $\begin{array}{l}\text {-increasing } \\
\text { the Investment in } \\
\text {-increasing } \\
\text { coverage }\end{array}$ & $\begin{array}{l}\text { Xu,X.P. ,\& Qing.J.(2018) ; } \\
\text { Liu, X.C.\&,Li.M.X.(2018); Huang, Y. P.(2019); } \\
\text { Zhu,X.J.,\&Song,R.Y.(2018) ; } \\
\text { Killian,D.,\& Kabanda,S. (2017); } \\
\text { Lone,S., Fávero,I.,\& Packiarajah,S.(2018) }\end{array}$ \\
\hline $\begin{array}{l}\text { The development of } \\
\text { the mobile } \\
\text { communication }\end{array}$ & $\begin{array}{l}\text {-mobile penetration is high } \\
\text {-mobile payments are } \\
\text { becoming more accessible }\end{array}$ & $\begin{array}{l}\text { Xu,X.P.,\& Qing.J(2018); } \\
\text { Liu, X.C.,\&Li.M.X.(2018; } \\
\text { Huang, Y. P.(2019) ; Wu, G. X. ,\& Guo,W.G. (2019); } \\
\text { Liu,R.Y.,\&Wang,Z.(2019); Zhu,X.J.,\&Song,R.Y.(2018); } \\
\text { China-africa Trade Research Center. (2019) }\end{array}$ \\
\hline $\begin{array}{lr}\text { Low revel } & \text { of } \\
\text { development } & \text { of local } \\
\text { e-commerce } & \text { industry } \\
\text { indicating } & \text { big } \\
\text { potential market } & \end{array}$ & $\begin{array}{l}\text {-limited offline shops } \\
\text {-scarce commodities } \\
\text {-product supply relies on } \\
\text { imports } \\
\text {-goods made in China are } \\
\text { abundant }\end{array}$ & $\begin{array}{l}\text { Hou, Y. L. (2018); } \\
\text { Li, Z.B. (2016); UNDIO (2015); } \\
\text { Liu,R.Y.,\&Wang,Z.(2019) }\end{array}$ \\
\hline $\begin{array}{l}\text { Rapidly increasing } \\
\text { market size }\end{array}$ & $\begin{array}{l}\text {-rapid population growth } \\
\text {-large demand in the e- } \\
\text { commerce market } \\
\text {-rapid growth of the middle } \\
\text { class and their purchase } \\
\text { power }\end{array}$ & $\begin{array}{l}\text { Zhu,X.J.,\&Song,R.Y.(2018); Kaplan, M.(2018); } \\
\text { Liu, X.C.,\&Li.M.X.(2018); Pison,G.( 2017); } \\
\text { Economic and Commercial Office of the Embassy in the } \\
\text { Republic of Congo.(2014); } \\
\text { Xu,X.P. ,\& Qing.J.(2018); Liu,R.Y.,\&Wang,Z.(2019) }\end{array}$ \\
\hline $\begin{array}{l}\text { Support of e- } \\
\text { commerce by policies } \\
\text { and regulations }\end{array}$ & $\begin{array}{l}\text {-various national policies } \\
\text { support } \\
\text {-free trade area agreements }\end{array}$ & $\begin{array}{l}\text { Economic and Commercial Office of the Embassy in Nigeria } \\
\text { (2015); } \\
\text { Lone,S., Fávero,I.,\& Packiarajah,S.(2018); } \\
\text { Budree,A.( 2017); Huang,Y.P. (2019); } \\
\text { Economic and Commercial Office of the Embassy in } \\
\text { Guinea, 2019; } \\
\text { Zhang, M.,\&Wang,X.P.(2019); } \\
\text { Xu, X.P.,\&Qing,J.(2018) }\end{array}$ \\
\hline
\end{tabular}

Table 2: Main challenges facing China-Africa cross-border e-commerce

\begin{tabular}{|c|c|c|}
\hline Theme & Challenges & Source \\
\hline High logistics costs & $\begin{array}{l}\text {-lack of electricity, poor } \\
\text { transportation } \\
\text {-large proportion of rural } \\
\text { population } \\
\text {-insufficient broadband networks } \\
\text {-limited port construction in } \\
\text { inland cities }\end{array}$ & 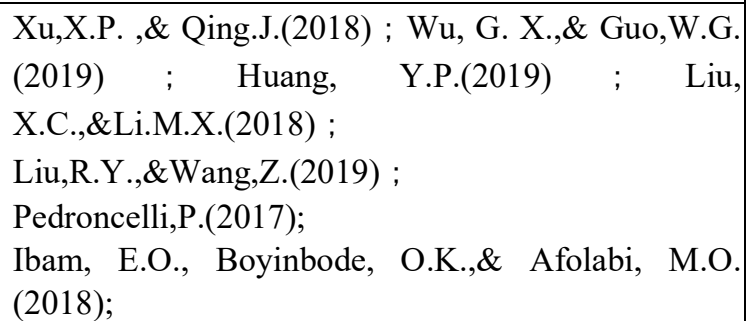 \\
\hline
\end{tabular}




\begin{tabular}{|c|c|c|}
\hline & $\begin{array}{l}\text { - lack of street address systems } \\
\text { - local delivery services not yet } \\
\text { well developed }\end{array}$ & $\begin{array}{l}\text { Matthews,C.(2016); Li, Q. (2018); } \\
\text { Calderón,C., Cantú,C.,\& Chuhan-Pole,P.(2018) }\end{array}$ \\
\hline $\begin{array}{l}\text { Obstacles for online } \\
\text { payment }\end{array}$ & $\begin{array}{l}\text {-limited accessibility of banking } \\
\text { services, lack of sophisticated } \\
\text { banking products } \\
\text {-low credit/debit card holding } \\
\text { rate, low acceptance of credit card } \\
\text { online payment } \\
\text {-foreign exchange control } \\
\text {-inability to access electronic trust } \\
\text { tools } \\
\text {-insecure cross-border banks and } \\
\text { financial networks } \\
\text {-lack of laws and regulations on } \\
\text { mobile payment }\end{array}$ & $\begin{array}{l}\text { Song, W. (2019) ; Liu,R.Y.,\&Wang,Z.(2019) ; } \\
\text { Xu,X.P. ,\& Qing.J(2018) ; Li, Q.(2018); } \\
\text { Ibam et al.(2018); “Mobile Report Nigeria } \\
2018 ” .(n . d .) ; \\
\text { Lone,S., Fávero,I.,\& Packiarajah,S.(2018); } \\
\text { Gutierrez, E. ,\& Choi, T. (2014) ; } \\
\text { Pedroncelli,P.(2017) }\end{array}$ \\
\hline $\begin{array}{l}\text { Limited trust in } \\
\text { processes } \\
\text { stakeholders }\end{array}$ & $\begin{array}{l}\text {-perceived lack of Internet } \\
\text { security } \\
\text {-distrust in online networks, } \\
\text { online websites, online payments } \\
\text {-high online fraud rates } \\
\text {-lack of mature e-commerce } \\
\text { systems } \\
\text {-inadequate laws and regulations } \\
\text {-lack of credit mechanisms in the } \\
\text { communication industry }\end{array}$ & $\begin{array}{l}\text { Song, W. (2019) ; UNCTAD.( 2015) ; Xu,X.P. , } \\
\text { \& Qing.J.(2018) Liu, X.C.,\&Li.M.X.(2018) ; } \\
\text { Wu, G. X. ,\& Guo,W.G. (2019) ; Siwicki,B.(2013) } \\
\text {; Huang, Y.P.(2019) ; Xu, X.P.,\&Wang,Z.(2018) ; } \\
\text { Zaied Abdel Nasser H..(2012) ; } \\
\text { Meltzer,J.( 2014); }\end{array}$ \\
\hline Market entry barriers & $\begin{array}{l}\text {-complex customs clearance } \\
\text { procedures } \\
\text {-difficult customs supervision } \\
\text {-high tariffs and tariff barriers }\end{array}$ & $\begin{array}{l}\text { "South Africa", (2019); Ibam, E.O., Boyinbode, } \\
\text { O.K., Afolabi, M.O. (2018); Xu,X.P. ,\& } \\
\text { Qing.J.(2018) ; Liu,R.Y.,\&Wang,Z.(2019) ; Huang, } \\
\text { Y.P.(2019) ; Song, W. (2019) ; Lawrence,J.E. } \\
\text { (2011); }\end{array}$ \\
\hline $\begin{array}{l}\text { Educational } \\
\text { background } \\
\text { population }\end{array}$ & $\begin{array}{l}\text {-low education level } \\
\text {-low literacy rate } \\
\text {-lack of specialized digital talent }\end{array}$ & $\begin{array}{l}\text { Xu,X.P. ,\& } \quad \text { Qing.J.(2018) ; } r \text { Liu, } \\
\text { X.C.,\&Li.M.X.(2018) ; Wu, G. X.,\& Guo,W.G. } \\
\text { (2019) ; Huang, Y. P.(2019) ; Valarezoa,Á.,Pérez- } \\
\text { Amaralb,T.,Garín-Muñozc,T.,Herguera } \\
\text { Garcíab,I.,\&Lópezb,R.(2018) ; Wanyonyi, P.(2018); }\end{array}$ \\
\hline Language barriers & $\begin{array}{l}\text {-language diversity, language } \\
\text { abilities and competence } \\
\text {-limited number of languages } \\
\text { available for e-commerce } \\
\text { websites }\end{array}$ & $\begin{array}{l}\text { Xu,X.P.,\& Qing.J.(2018) ; Wang,H. (2018) ; } \\
\text { Mzuku, K.( 2016) ; Turban E., King D., Lee J.K., } \\
\text { Liang T.-P., \& Turban D.C. (2015); }\end{array}$ \\
\hline
\end{tabular}

Table 3: Activities of governments and firms

\begin{tabular}{|l|l|l|l|}
\hline $\begin{array}{l}\text { Perspe } \\
\text { ctive }\end{array}$ & Theme & Activities (selected) & Source \\
\hline $\begin{array}{l}\text { Govern } \\
\text { ments }\end{array}$ & $\begin{array}{l}\text { Investment } \\
\text { transportation, } \\
\text { communication and } \\
\text { other infrastructure }\end{array}$ & $\begin{array}{l}\text {-Railway, highway and Internet } \\
\text { infrastructure construction } \\
\text {-China UnionPay Network has } \\
\text { established networks in more than } \\
50 \text { African countries } \\
\text {-China has committed to invest in } \\
\text { power and logistics in South Africa }\end{array}$ & $\begin{array}{l}\text { Economic and Commercial Office of the } \\
\text { Embassy in Senegal.(2017); } \\
\text { Ministry of Commerce of the PRC } \\
\text { Department of Electronic Commerce and } \\
\text { Informatization .(2018);Phoenix Business } \\
\text { Daily.(2018); } \\
\text { Fang, F. (2019); Huang, Y. P.(2019) }\end{array}$ \\
\hline
\end{tabular}




\begin{tabular}{|c|c|c|c|}
\hline & $\begin{array}{lr}\text {-Implementation } & \text { of } \\
\text { cross-border } & \text { e- } \\
\text { commerce } & \text { pilot } \\
\text { projects } & \\
\text {-Improvement } & \text { of } \\
\text { policies, regulations } \\
\text { and } \\
\text { processes }\end{array}$ & $\begin{array}{l}\text {-Implementation of "cross-border } \\
\text { e-commerce pilot city" and "cross- } \\
\text { border } \\
\text { comprehensiver experimental } \\
\text { zone" } \\
\text {-Benefitting from China's "Belt and } \\
\text { Road Initiative" to support Africa's } \\
\text { "Agenda 2063" } \\
\text {-Implementation of the "e-commerce } \\
\text { Law" }\end{array}$ & $\begin{array}{l}\text { Yang,J.L.(2017); } \\
\text { Zhang,Q.W.,\&Zhang,M.(2016); } \\
\text { Li,Q.(2018) }\end{array}$ \\
\hline \multirow[t]{6}{*}{ Firms } & $\begin{array}{ll}\begin{array}{l}\text { Localization } \\
\text { operations }\end{array} & \text { of }\end{array}$ & $\begin{array}{l}\text {-localized e-commerce website } \\
\text { and languages } \\
\text {-set up a localized management } \\
\text { team }\end{array}$ & $\begin{array}{l}\text { Jessica (2017); } \\
\text { Zhu,X.J.,\&Song,R.Y.(2018); } \\
\text { Li, W.Y. (2018) }\end{array}$ \\
\hline & $\begin{array}{ll}\text { Development } & \text { of } \\
\text { online payments }\end{array}$ & $\begin{array}{l}\text {-Kilimall cooperates with local } \\
\text { mobile payment providers for } \\
\text { online payment } \\
\text {-Tencent cooperates with Bank of } \\
\text { South Africa to develop WeChat } \\
\text { wallet service } \\
\text {-Alipay cooperates with South } \\
\text { African payment company Zappa } \\
\text { to develop online payment }\end{array}$ & $\begin{array}{l}\text { GSMA.(n.d); } \\
\text { Jessica.(2017); } \\
\text { Xu,R.(2015); } \\
\text { Li,Z.W.(2017) }\end{array}$ \\
\hline & $\begin{array}{l}\text { Overseas warehouse } \\
\text { construction and } \\
\text { logistics }\end{array}$ & $\begin{array}{l}\text {-Kilimall builds its own overseas } \\
\text { warehouse in Kenya } \\
\text {-Yuantong Express and Zimbabwe } \\
\text { Post establish an overseas } \\
\text { warehouse operation model } \\
\text {-China National Building } \\
\text { Materials Group proposes a "cross- } \\
\text { border digital trade and shared } \\
\text { overseas warehouse", an African- } \\
\text { oriented integrated service } \\
\text { operation model for foreign trade }\end{array}$ & $\begin{array}{l}\text { Jessica,(2017); } \\
\text { State Post Bureau of The People's Republic } \\
\text { of China.(2018); } \\
\text { Zhu,X.J.,\&Song,R.Y.(2018); } \\
\text { Secretariat of the First China-Africa } \\
\text { Economic and Trade Fair.(2019) }\end{array}$ \\
\hline & $\begin{array}{l}\text { Talent and skill } \\
\text { development }\end{array}$ & $\begin{array}{l}\text {-Huawei trains ICT professionals } \\
\text { for Africa } \\
\text {-Alibaba invites African } \\
\text { entrepreneurs to study e-commerce } \\
\text { knowledge and experience in } \\
\text { China and establishes a fund } \\
\text { support plan }\end{array}$ & $\begin{array}{l}\text { Xu,R.(2015); } \\
\text { Ibam et al. (2018); } \\
\text { Hou,Y.L.(2018); } \\
\text { GUO,Y.(2018); } \\
\text { AliResearch.(2019) }\end{array}$ \\
\hline & $\begin{array}{l}\text { Digital infrastructure } \\
\text { construction }\end{array}$ & $\begin{array}{l}\text {-Huawei builds information and } \\
\text { communication technology } \\
\text { innovation experience centers } \\
\text {-ZTE builds communication } \\
\text { networks for African governments } \\
\text { and enterprises } \\
\text {-Alibaba and the Kenyan Animal } \\
\text { Protection Department jointly } \\
\text { develop the "Kenya Wildlife } \\
\text { Intelligent Protection Project" }\end{array}$ & $\begin{array}{l}\text { Zhang,J.X.(2015); } \\
\text { Xinhua News Agency.(2017); } \\
\text { AliResearch.(2019); } \\
\text { Liu,R.Y.,\&Wang,Z.(2019) }\end{array}$ \\
\hline & $\begin{array}{l}\text { Establishment of } \\
\text { integration platforms }\end{array}$ & $\begin{array}{l}\text {-"China-Africa Comprehensive } \\
\text { Supply Chain Integrated Services }\end{array}$ & $\begin{array}{l}\text { Liu, X.C.,\&Li.M.X.(2018); } \\
\text { Hou, Y.L.(2018); } \\
\text { Zhang, M.,\&Wang,X.P. (2019) }\end{array}$ \\
\hline
\end{tabular}




\begin{tabular}{|l|l|l|}
\hline & $\begin{array}{l}\text { for Cross-border E-commerce } \\
\text { Platform" launched } \\
\text {-Alibaba's eWTP (Electronic } \\
\text { World Trade Platform) Platform } \\
\text { established in Rwanda }\end{array}$ \\
\hline
\end{tabular}




\section{References}

AliResearch. (2019). Building the 21st Century Digital Silk Road: Alibaba's Economic Practice.Retrieved from http://www.199it.com/archives/868119.html

Budree, A. (2017). E-commerce country case study: South Arica. Retreive from the Global Economic Governance website http://www.gegafrica.org/publications/e-commerce-country-case-study-south-africa

Calderón,C., Cantú,C.,\& Chuhan-Pole, P. (2018). Infrastructure Development

in Sub-Saharan Africa: $A$ Scorecard. Retrieved from http://documents.worldbank.org/curated/en/866331525265592425/pdf/Infrastructure-development-in-SubSaharan-Africa-a-scorecard.pdf

China-Africa Trade Research Center. (2019). Mobile subscribers will be more than half of all users in sub-Saharan Africa by 2025. Retreive from the China-Africa Trade Research Center website:http://news.afrindex.com/zixun/article11948.html

Economic and Commercial Office of the Embassy in Guinea. (2019). The African Continental Free Trade Area will take effect on May 30, 2019, and will be officially implemented on July 7. Retrieved from

http://www.mofcom.gov.cn/article/i/jyjl/k/201905/20190502860158.shtml

Economic and Commercial Office of the Embassy in Nigeria.(2015).E-commerce in Nigeria grows rapidly with an average annual growth rate of $25 \%$. Retrieved from

http://www.mofcom.gov.cn/article/i/dxfw/gzzd/201510/20151001145336.shtml

Economic and Commercial Office of the Embassy in the Republic of Congo. (2014). Africa's growing middle class. Retrieved from http://www.mofcom.gov.cn/article/i/jyjl/k/201409/20140900727822.shtml

Economic and Commercial Office of the Embassy in Senegal. (2017). China is the largest investor in Africa's infrastructure construction. Retrieve from http://senegal.mofcom.gov.cn/article/jmxw/201710/20171002661137.shtml

Fang, F. (2019). Construction of the "Digital Silk Road": International Environment and Path Choice. International Forum, (2), 72.

Global System for Mobile Communications Alliance (GSMA). (2017). State of the Industry Report on Mobile Money.Retrieved

from https://www.gsma.com/mobilefordevelopment/wpcontent/uploads/2018/05/GSMA_2017_State_of_the_In dustry_Report_on_Mobile_Money_Full_Report.pdf

Guo, S.W., Ming, A., Wang, Q., \& $\bar{Z}$ hu, X. Q. (2018). The "New Engine of Foreign Trade" with a New Normal: The Development and Transformation of China's Cross-border E-commerce Trade. Economist, 42-49

Guo, Y. (2018). Alibaba: Assisting Africa's Digital Economy and Supporting African Youth's Entrepreneurial Dream - Interview with Huang Mingwei, Vice President of Global Innovation and Development of Alibaba Group. China's Foreign Trade, 38-39.

Gutierrez,E.,\& Choi,T. (2014). Mobile money services development: the cases of the Republic of Korea and Uganda . Retrieved from the World Bank website: http://documents.worldbank.org/curated/en/503961468174904206/Mobile-money-services-developmentthe-cases-of-the-Republic-of-Korea-and-Uganda .

Hou,Y.L.(2018, September 7). Alibaba helps Africa embrace digital economy. Economic Information Daily, p.3. Retrieved from: http://jjckb.xinhuanet.com/2018-09/07/c_137451035.htm

Huang,Y. P. (2019). China-Africa Joint Construction of the "Digital Silk Road": Opportunities, Challenges and Path Choices.International Studies, (4),50-63.

Ibam, E. O., Boyinbode, O. K., \& Afolabi, M. O. (2018). e-Commerce in Africa: The Case of Nigeria. EAI Endorsed Transactions on Game-Based Learning, 4(15),1-6.doi: 10.4108/eai.5-1-2018.153536

Jessica. (2017, January 10). KilimallFounder Yang Tao: African e-commerce is our lifelong business. Retrieved from http://www.baijingapp.com/article/9638

Kaplan, M. (2018). Africa: An Emerging Ecommerce Market with Many Challenges. Retrieve from the Pratical Ecommerce website: https://www.practicalecommerce.com/africa-emerging-ecommerce-market-manychallenges

Killian, D. \& Kabanda, S. (2017). Mobile Payments In South Africa: Middle Income Earners' Perspective. PACIS 2017 Proceedings. 53. Retrieved from https://aisel.aisnet.org/pacis2017/53

Lawrence, J. E. (2011). The growth of e-commerce in developing countries: an exploratory study of opportunities and challenges for SMEs. International Journal of ICT Research, 2(1),15-28. doi:10.4018/978-1-46663607-1.ch003

Li, Q. (2018, September 9). New opportunities for China-Africa trade facilitation and cross-border e-commerce cooperation. China Business News. Retrieved from https://www.yicai.com/news/100023745.html 
Li, R. M. (2020). China's cross-border e-commerce development assessment and promotion strategy.Zhejiang Academic Journal ,(3) ,151-156. doi:10.16235/j.cnki.33-1005/c.2020.03.019

Li, W. Y. (2018, October 31). Ali upgrades machine translation with 48 languages supported. Retrieved from: http://industry.people.com.cn/n1/2018/1031/c413883-30374172.html

Li, Z. B. (2016). Strategic thinking on Africa's industrialization strategy and China-Africa cooperation. West Asian and Africa, (5), 107-111.

Li, Z. W. (2017, October 10). China Mobile Payments sets a benchmark in Africa.People's Daily. Retrieved from: http://ydyl.people.com.cn/n1/2017/1010/c411837-29577552.html

Liu, R. Y. \& Wang, Z. (2019). Africa B2C e-commerce should develop differently. China Investment, (2),74-75.

Liu, X. C. \& Li, M. X. (2018). China-Africa cross-border e-commerce is booming and challenges need to be vigilant. China's Foreign Trade, 62-63.

Lone, S., Fávero, I. \& Packiarajah, S. (2018). 2018 Africa Ecommerce Report. Retrieved from the EcommerceWIKI website: https://www.ecommercewiki.org/reports/767/africa-ecommerce-report-2018-free

Matthews, C. (2016, February 1). Finding your way in a country without street addresses. BBC NEWS. Retrieve from https://www.bbc.com/news/world-africa-35385636

Meltzer,J.(2014). Supporting the internet as a platform for international trade: opportunities for small and mediumsized enterprises and developing countries. Global economy and development working paper, 69. doi: $10.2139 / \mathrm{ssrn} .2400578$

Ministry of Commerce of the People's Republic of China, Department of Electronic Commerce and Informatization. (2018). China E-Commerce Report ( 2017 ) .Retrieved from: http://dzsws.mofcom.gov.cn/article/ztxx/ndbg/201805/20180502750562.shtml

Mobile Report Nigeria 2018. (n.d.) Retrieved March 21, 2019, from https://www.jumia.com.ng/mobile-report-2018/

Mzuku, K. (2016). These Are the Barriers E-Commerce Needs To Overcome Before It Can Really Take Off In Africa. Retrieve from https://www.iafrikan.com/2016/08/11/these-are-the-barriers-e-commerce-needs-toovercome-before-it-can-really-take-off-in-africa/

Pedroncelli, P. (2017). 10 Obstacles That Impede Africa's International E-Commerce Growth. Retrieve from https://moguldom.com/139961/10-obstacles-that-impede-africas-international-e-commerce-growth/11/

Phoenix Business Daily. (2018, July 25). China to invest \$ 14.7 billion in South Africa, South African Rand up 1.2\% . Retrieve from the Weekly on Stocks website: http://news.hongzhoukan.com/18/0725/liwan133047.html

Pison, G. (2017). There is a strong chance a third of all people on earth will be African by 2100. Retrieved from the Conversation website: https://qz.com/africa/1099546/population-growth-africans-will-be-a-third-of-allpeople-on-earth-by-2100/

Secretariat of the Organizing Committee of the First China-Africa Economic and Trade Fair. (2019). China-Africa economic and trade cooperation case plan collection (Part 1)__ African case of "cross-border digital trade + sharing overseas warehouses." Hunan People's Publishing House, 108-109.

Siwicki, B. (2013). 7\% of online transactions in Africa are fraudulent. Retrieve from

https://www.digitalcommerce360.com/2013/02/28/7-online-transactions-africa-are-fraudulent/

Song, W. (2019, Jane 12). African free trade zone brings new opportunities for Chinese enterprises. Global Times. Retrieved from https://www.huanqiu.com/

South Africa - Import Requirements and Documentation. (2019). Retrieved May 17, 2020, from https://www.export.gov/apex/article2?id=South-Africa-import-requirements-and-documentation

State Post Bureau of The People's Republic of China. (2018, September 21). Chinese company injected into African e-commerce delivery market. Retrieved from the State Post Bureau of the People's Republic of China website: http://www.spb.gov.cn/xw/hqyz_1/ggyzxx/201809/t20180921_1661255.html

Turban, E., King, D., Lee, J. K., Liang, T. P., \& Turban, D. C. (2015). Overview of Electronic Commerce. In Electronic Commerce,3-49. Switzerland: Springer. Doi:https://doi.org/10.1007/978-3-319-10091-3_1

United Nations Conference on Trade and Development (UNCTAD) (2015). Information Economy Report 2015" Unlocking the Potential of E-Commerce for Developing Countries" Retrieve from the UNCTAD website: https://unctad.org/en/PublicationsLibrary/ier2015_en.pdf

United Nations Industrial Development Organization (UNIDO). (2015). Industrial Development Report 2016. The Role of Technology and Innovation in Inclusive and Sustainable Industrial Development. Retrieved from http://images.mofcom.gov.cn/vienna/201601/20160110185030746.pdf

Valarezoa, Á. P, érez-Amaralb, T., Garín-Muñozc, T., Herguera Garcíab, I., \& Lópezb, R. (2018). Drivers and Barriers to cross-border e-commerce: Evidence from Spanish individual behavior. In Telecommunications Policy,42(6), 464-473.Retrieved from https://doi.org/10.1016/j.telpol.2018.03.006

Wang, H. (2018, September 24). Linguistic Diversity in Africa and China-Africa Cooperation. Guangming Daily.p.8. Wanyonyi, P. (2018). E-commerce: Poor infrastructure holds Africa back.

Retrieve from http://www.nairobibusinessmonthly.com/e-commerce-poor-infrastructure-holds-africa-back/ 
Wu, G. X. \& Guo, W. G. (2019). Opportunities and challenges faced by China-Africa cross-border e-commerce cooperation under the 'Belt and Road' Initiative. Practice in Foreign Economic Relations and Trade,28-31. doi:10.3969/j.issn.1003-5559.2019.03.007

Xinhua News Agency. (2017, August 11). Huawei South Africa ICT Innovation Experience Center. XinHuaNet. Retrieved from http:// www.xinhuanet.com//photo/2017-08/11/c_1121470823.htm

$\mathrm{Xu}, \mathrm{H}$. (2015, December 16). Huawei trains more than 30,000 communications technicians in Africa. Economic Daily. P.2.

Xu, R. (2015, December 2). WeChat wallet goes global .21st Century Business Herald.

Retrieved from: http://www.21jingji.com/2015/12-2/xMMDEwODZfMTM4NTExMw.html

Xu, X. P. \& Qing, J. (2018). Analysis of the Motives and Obstacles of China-Africa Cross-border E-commerce. Practice in Foreign Economic Relations and Trade, 21-24.

Yang, J. L. (2017). Africa's economic and trade highlights:cross-border e-commerce boost foreign trade .China Tendering Weekly,16-17.

Zaied Abdel Nasser H. (2012). Barriers to e-Commerce adoption in Egyptian SMEs. I.J. Information Engineering and Electronic Business,3,9-18.

doi: 10.5815/ijieeb.2012.03.02

Zhang, J. X. (2015, December 8). Creating the 'Information Silk Road': ZTE helps African countries modernize and transform. People's Daily Online. Retrieved from http://world.people.com.cn/n/2015/1208/c100227901916.html

Zhang, M \& Wang, X. P. (2019). E-commerce Connects Rwanda to the World - Interview with Charles Kayonga, Rwanda Ambassador to China.China Investment, 26-28.

Zhang, Q. W. \& Zhang, M. (2016). Rethinking China-Africa economic and trade cooperation under the new normal .Journal of International Economic Cooperation,(7):33-36.

Zhu, X. J. \& Song, R. Y. (2018, July). An analysis of the "going global" of online information companies and investment opportunities in Africa .China National Conditions and Strength,28-30. doi:10.13561/j.cnki.zggqgl.2018.07.009 